\title{
Pengaruh Kepemimpinan dan Kepuasan Kerja Terhadap Kinerja Dosen di Universitas Majalengka, Jawa Barat
}

\author{
Dita Cucu Kartika1, Ma'ruf Akbar², Rugaiyah² \\ ${ }^{1}$ Manajemen Pendidikan, Program Pascasarjana Universitas Pasundan \\ ${ }^{2}$ Universitas Negeri Jakarta
}

\section{ARTICLE INFO}

\section{Article History:}

Received 18.01.2018

Received in revised

form 11.02.2018

Accepted 20.03.2018

Available online

10.04.2018

\begin{abstract}
The objective of this research is to understand comprehensively the effect of empowerment and job satisfaction toward job performance of lecturer in Majalengka University, West Java. A survey method with path analysis techniques was used by applying a questioner as a research instrument. 80 responders were involved by sending their feedback within the questioner. Those responders were decided using simple random sampling among all lecturers that working at the Majalengka University. The data result, analysis and interpretation reveal that (1) empowerment has a direct positive effect toward job performance, (2) job satisfaction has a direct positive effect toward job performance, (3) empowerment has a direct positive effect toward job satisfaction.
\end{abstract}

Keywords:

Empowerment, Job Performance, Job Satisfaction.

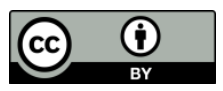

This is an open access article distributed under the terms of the Creative Commons Atribution 4.0 International License, which permits unrestricted use, distribution, and reproduction in any medium, provided the original work is properly cited. @ 2018 Dita Cucu Kartika, Ma'ruf Akbar, Rugaiyah.

\section{PENDAHULUAN}

Era globalisasi merupakan era persaingan dimana setiap organisasi berlomba untuk menjadi yang terbaik dalam berbagai kompetisi baik secara external maupun internal. Demikian pula dengan organisasi pendidikan yang turut serta dalam persaingan tersebut, harus melakukan inovasi kreatif agar mampu bersaing dan akhirnya berdampak pada peningkatan mutu pendidikan dan pencapaian tujuan organisasi itu sendiri.

Untuk mencapai tujuan organisasi pendidikan, dibutuhkan sumber daya manusia (SDM) yang mampu dan profesional disetiap bidang ilmunya. Isu sentral yang sering dijadikan kajian berkaitan dengan sumber daya manusia dalam suatu organisasi pendidikan adalah kinerja, maka kelancaran dan keberhasilan penyelesaian suatu pekerjaan, sangat ditentukan oleh kualitas sumber daya yang dimiliki, baik sumber daya alam maupun sumber daya manusia.

Sumber daya manusia merupakan satu-satunya sumber daya yang memiliki rasio, rasa dan karsa yang berpengaruh terhadap upaya organisasi dalam pencapaian tujuan. Oleh karena itu, investasi manusia merupakan investasi paling penting yang dapat dilakukan oleh organisasi yang tujuannya bermuara pada satu titik akhir yaitu agar organisasi memiliki tenaga kerja yang disiplin,

${ }^{1}$ Corresponding author's address: Universitas Pasundan, Bandung, Indonesia e-mail: dita.cucu.kartika@gmail.com 
berdedikasi, loyalitas, memiliki efisiensi, efektivitas dan produktivitas kerja yang dapat memenuhi kebutuhan organisasi, untuk saat ini dan masa yang akan datang.

Perguruan tinggi sebagai salah satu organisasi pendidikan, memiliki sumber daya manusia yang profesional yaitu Dosen. Disadari atau tidak, mutu Dosen dalam suatu perguruan tinggi merupakan salah satu faktor yang mempengaruhi mutu organisasi. Melihat kenyataan tersebut, peningkatan kinerja dosen merupakan suatu kebutuhan pasti yang bertujuan untuk merubah perilaku mereka menjadi perilaku yang lebih mampu melaksanakan aktifitas disegala bidang, karena pada dasarnya perilaku manusia dapat mempengaruhi setiap tindakan dalam mencapai tujuan yang ingin dicapai. Menurut Sedarmayanti (2011: 263) "Kinerja pegawai pada dasarnya merupakan hasil kerja seorang pegawai selama periode tertentu dibandingkan dengan berbagai kemungkinan, misalnya: standard, target/sasaran/kriteria yang ditentukan dan disepakati bersama."

Kinerja atau prestasi kerja merupakan tingkat keberhasilan seseorang dalam melaksanakan dan menyelesaikan suatu pekerjaan. Tingkat keberhasilan ini disebut level of performance atau level kinerja. Pegawai yang memiliki level kinerja yang tinggi merupakan pegawai yang produktivitas kerjanya tinggi, begitupun sebaliknya, pegawai yang memiliki level kinerja tidak sesuai dengan standar yang telah ditetapkan, maka pegawai tersebut dikatakan sebagai pegawai yang tidak produktif. Menurut Rivai (2011;14, “kinerja sebagai hasil atau tingkat keberhasilan seseorang secara keseluruhan selama periode tertentu didalam melaksanakan tugas dibandingkan dengan berbagai kemungkinan".Kinerja merupakan prestasi nyata yang ditampilkan seseorang setelah yang bersangkutan menjalankan tugas dan perannya dalam organisasi.

Salah satu faktor yang dianggap berpengaruh terhadap kinerja seseorang, khususnya kinerja dosen di Universitas Majalengka, adalah pemberdayaan. Pemberdayaan adalah pemberian wewenang dan tanggung jawab kepada orang lain dengan tujuan untuk meningkatkan aktualisasi diri sehingga orang tersebut lebih berdaya guna dan mampu memimpin dirinya sendiri dan orang lain. Pemberdayaan terjadi ketika seseorang mengalami peningkatan wewenang dan tanggung jawab, termasuk kemampuannya secara individu. Peningkatan ini tentunya berdampak positif terhadap apa yang dikerjakannya, sehingga berdampak pula pada hasil kerjanya. Schemerhorn $(2010 ; 54)$ mengemukakan bahwa "empowerment allow other to make decisions and exercise discretion in their work". Pemberdayaan memungkinkan orang lain untuk membuat keputusan dan kebijaksanaan latihan dalam pekerjaannya. Dengan keputusan dan kebijaksanaan dalam melakukan pekerjaan, maka seseorang dapat mencapai hasil yang baik dalam pekerjaannya. Pemberdayaan yang dimaksud dapat dilakukan melalui berbagai macam cara antara lain melalui pengiriman para pegawai atau Dosen untuk mengikuti berbagai pelatihan dan pendidikan, mengikuti berbagai lomba sesuai dengan keahliannya, mengikuti jenjang pendidikan yang lebih tinggi, membuat karya ilmiah, pemindahan dan intervensi organisasi.

Selain faktor pemberdayaan, faktor lain yang diduga berpengaruh terhadap kinerja adalah kepuasan kerja. Secara umum, kepuasan kerja menggambarkan bagaimana sikap dan perasaan seseorang terhadap pekerjaannya. Seseorang yang merasa puas pada pekerjaannya akan menunjukkan sikap senang saat bekerja atau sebaliknya, seseorang yang tidak puas pada pekerjaannya akan menunjukkan sikap kurang bersemangat dalam bekerja. Kepuasan kerja itu tidak nampak secara nyata tetapi dapat terwujud dalam suatu hasil pekerjaan.

Kepuasan kerja dapat dirasakan oleh setiap orang termasuk Dosen yang memiliki peran strategis dalam perkembangan dan kemajuan perguruan tinggi. Kepuasan kerja Dosen perlu mendapat perhatian dalam hal pemenuhan kebutuhan. Pemenuhan kebutuhan bukan hanya sekedar memenuhi kebutuhan hidup tetapi juga pemenuhan secara psikologis seperti mendapatkan promosi, penghasilan yang memadai, lingkungan kerja yang kondusif dan hubungan timbal balik antara pemimpin dan Dosen serta antar sesama rekan kerja. Seberapa besar harapan yang akan dicapai dari pekerjaannya, berdampak pada sikap senang atau tidak senang Dosen terhadap pekerjaannya. Dosen yang senang terhadap pekerjaannya menunjukkan sikap kinerja yang lebih positif dengan lebih kreatif dan lebih kompetitif dalam mencapai tujuan organisasi. Sedangkan 
Dosen yang tidak senang akan pekerjaannya akan menunjukkan kinerja yang lebih negatif yang dapat mengakibatkan pemangkiran dalam bekerja. Pemenuhan kebutuhan yang menimbulkan rasa puas tidak hanya menguntungkan bagi pihak Dosen saja tetapi menguntungkan juga bagi organisasi.

Berdasarkan uraian di atas, Peneliti merasa perlu untuk mengkaji secara ilmiah kinerja yang dipengaruhi oleh faktor-faktor pemberdayaan dan kepuasan kerja di lingkungan Universitas Majalengka.

Observasi yang dilakukan peneliti pada 19 Oktober 2016, didapat informasi bahwa jumlah tenaga pengajar tercatat 205 orang yang terdiri dari Dosen Tetap Yayasan dan Dosen DPK. Selain itu, terdapat pula Dosen luar biasa yang berjumlah 84 orang. Universitas Majalengka yang berdiri sejak tahun 1984 memiliki prioritas utama yang perlu dikembangkan, yaitu penambahan jumlah tenaga pengajar yang berstatus Dosen Biasa (DB), yang saat ini masih sangat terbatas yaitu hanya sekitar $30 \%$ dari total tenaga pengajar. Penambahan Dosen Biasa yang memiliki jabatan akademik akan tetap menjadi prioritas yayasan, yang dalam pengangkatannya disesuaikan dengan kemampuan finansial masing-masing perguruan tinggi. Tenaga pengajar ini akan banyak memiliki arti bagi peningkatan status akreditasi dan kemandirian perguruan tinggi yang bersangkutan.

Selanjutnya, hasil observasi juga menunjukkan temuan bahwa setiap Dosen memiliki persepsi yang berbeda mengenai kepuasan kerja terhadap pekerjaannya. Apabila dilihat dari masa kerja, Dosen dengan masa kerja di atas 20 tahun cenderung merasa puas dengan pekerjaannya karena pengaruh usia yang membuat dia lebih dewasa dan matang dalam berfikir tentang tujuan hidup, harapan, dan keinginan. Selain itu juga dari segi penghasilan sudah cukup terjamin. Sedangkan pada Dosen dengan masa kerja dibawah 20 tahun, memiliki semangat dan harapan yang besar untuk mencapai suatu tujuan, seperti mendapatkan promosi jabatan, penghasilan yang memadai dan kesempatan untuk berkembang secara intelektual dan memperluas bidang keilmuan yang dimilikinya. Besar kecilnya harapan yang dicapai akan menjadi sebuah penilaian terhadap kepuasan kerja.

Kemudian, terdapat pula masalah-masalah yang berkaitan dengan kinerja Dosen antara lain kurangnya hasil karya-karya Dosen dalam perannya sebagai Peneliti. Hal ini terlihat dari sangat sedikitnya buku ajar atau penulisan karya ilmiah pada beberapa tahun terakhir yang tentunya mempengaruhi persyaratan untuk mendapatkan kenaikan pangkat/jabatan. Selain itu, masalah ketersediaan tenaga pengajar yang memberikan pengajaran tidak sesuai dengan bidang keilmuan yang dimilikinya. Hal ini menimbulkan ketidakpercayaan diri dan penurunan kinerja dalam memberikan materi perkuliahan.

Berdasarkan data observasi, misalnya pada fakultas pertanian terdapat Dosen dengan latar belakang sarjana pendidikan (S.Pd.) mengajar mata kuliah sistem agrobisnis, pengantar ilmu pertanian, ekonomi makro, dan sebagainya. Hal ini menimbulkan ketidakpuasan Dosen dalam hal penguasaan materi sehingga Dosen merasa kurang percaya diri dan tidak optimal dalam memberikan pengajaran, pada akhirnya berdampak pula pada hasil kerja dosen tersebut.

Masih adanya Dosen yang tidak disiplin dalam bekerja, sering mangkir dari jadwal perkuliahan, datang tidak tepat waktu, kurang perduli terhadap kegiatan-kegiatan sosial, berfikir negatif terhadap pimpinan atau rekan kerja dan sebagainya. Hal ini terlihat dari hasil penilaian Dosen di tahun 2015-2016. Selain itu, kurang pula pemerataan kesempatan para Dosen untuk melakukan pelatihan dan pendidikan yang dapat mengoptimalkan pemberdayaan dan mendukung jenjang karirnya.

\section{METODE}

Penelitian ini menggunakan metode kuantitatif, dengan metode survey. Proses pengumpulan data dilakukan dengan menggunakan angket sebagai instrumen penelitian. Variable yang diteliti terdiri dari dua jenis yaitu variabel eksogen dan variabel endogen. Dalam penelitian ini, variabel eksogen yaitu pemberdayaan dan kepuasan kerja. Sedangkan variabel endogen yaitu kinerja. Variabel kinerja terdiri dari 3 indikator dengan 30 butir pernyataan yang diujicobakan. Setelah 30 butir pernyataan ini diujicobakan selanjutnya dilakukan analisis uji validitas butir, dari hasil perhitungan 
terdapat 4 butir pernyataan yang tidak valid sehingga dinyatakan gugur (drop) karena rhitung lebih kecil dari rtabel. Instrumen penelitian yang telah teruji validitasnya selanjutnya dilakukan uji reliabilitas, dengan besaran koefisien reliabilitas sebesar $=0,893$ untuk variabel kinerja. Selanjutnya variabel pemberdayaan terdiri dari 4 indikator dengan 30 butir pernyataan yang diujicobakan. Setelah 30 butir pernyataan ini diujicobakan selanjutnya dilakukan analisis uji validitas butir, dari hasil perhitungan terdapat 5 butir pernyataan yang tidak valid sehingga dinyatakan gugur (drop) karena rhitung lebih kecil dari rtabel. Instrumen penelitian yang telah teruji validitasnya selanjutnya dilakukan uji reliabilitas, dengan besaran koefisien reliabilitas sebesar $=0,902$ untuk variabel pemberdayaan. Untuk variabel kepuasan kerja terdiri dari 4 indikator dengan 35 butir pernyataan yang diujicobakan. Setelah 35 butir pernyataan ini diujicobakan selanjutnya dilakukan analisis uji validitas butir, dari hasil perhitungan terdapat 4 butir pernyataan yang tidak valid sehingga dinyatakan gugur (drop) karena rhitung lebih kecil dari rtabel. Instrumen penelitian yang telah teruji validitasnya selanjutnya dilakukan uji reliabilitas, dengan besaran koefisien reliabilitas sebesar $=$ 0,947 untuk variabel kepuasan kerja.

\section{HASIL DAN PEMBAHASAN}

Penelitian ini menggunakan pengujian persyaratan analisis yang terdiri dari uji normalitas, (2) uji signifikansi dan linearitas koefisien regresi. Dari hasil perhitungan uji normalitas (perhitungan secara lengkap pada lampiran 5) diperoleh hasil sebagai berikut:

\section{Uji Normalitas Galat Taksiran Regresi $X_{3}$ atas $X_{1}$}

Dari hasil perhitungan diperoleh nilai Lhitung $=0,0602$ nilai ini lebih kecil dari nilai Ltabel $(\mathrm{n}=80 ; \alpha=$ 0,05) sebesar 0,099. Mengingat nilai Lhitung lebih kecil dari Ltabel maka sebaran data kinerja atas pemberdayaan cenderung membentuk kurva normal.

\section{Uji Normalitas Galat Taksiran Regresi $X_{3}$ atas $X_{2}$}

Dari hasil perhitungan diperoleh nilai Lhitung $=0,0368$ nilai ini lebih kecil dari nilai Ltabel $(\mathrm{n}=80 ; \alpha=$ 0,05) sebesar 0,099. Mengingat nilai Lhitung lebih kecil dari Ltabel maka sebaran data kinerja atas kepuasan kerja cenderung membentuk kurva normal.

\section{Uji Normalitas Galat Taksiran Regresi $X_{2}$ atas $X_{1}$}

Dari hasil perhitungan diperoleh nilai Lhitung $=0,0546$ nilai ini lebih kecil dari nilai Ltabel $(\mathrm{n}=80 ; \alpha=$ $0,05)$ sebesar 0,099. Mengingat nilai Lhitung lebih kecil dari Ltabel maka sebaran data kepuasan kerja atas pemberdayaan cenderung membentuk kurva normal.

Berdasarkan hal tersebut, maka dapat disimpulkan bahwa semua hipotesis nol $\left(\mathrm{H}_{0}\right)$ yang berbunyi sampel berasal dari populasi berdistribusi normal tidak dapat ditolak, dengan kata lain bahwa semua sampel yang terpilih berasal dari populasi yang berdistribusi normal. Rekapitulasi hasil perhitungan pengujian normalitas terlihat pada tabel berikut:

Tabel 1. Hasil Pengujian Normalitas Galat Taksiran Regresi

\begin{tabular}{lccccl}
\hline \multicolumn{1}{c}{$\begin{array}{c}\text { Galat Taksiran } \\
\text { Regresi }\end{array}$} & \multirow{2}{*}{$\mathrm{n}$} & \multirow{2}{*}{ Lhitung } & \multicolumn{2}{c}{ Ltabel } & \multirow{2}{*}{ Keterangan } \\
\cline { 4 - 5 } & & & $\alpha=0,05$ & $\alpha=0,01$ & \\
\hline $\mathrm{X}_{3}$ atas $\mathrm{X}_{1}$ & 80 & 0,0602 & 0,099 & 0,113 & Normal \\
\hline $\mathrm{X}_{3}$ atas $\mathrm{X}_{2}$ & 80 & 0,0368 & 0,099 & 0,113 & Normal \\
\hline $\mathrm{X}_{2}$ atas $\mathrm{X}_{1}$ & 80 & 0,0546 & 0,099 & 0,113 & Normal \\
\hline
\end{tabular}

Berdasarkan harga-harga Lhitung dan Ltabel di atas dapat disimpulkan pasangan semua data baik kinerja atas pemberdayaan, kinerja atas kepuasan kerja, dan kepuasan kerja atas pemberdayaan berasal dari sampel yang berdistribusi normal.

Selanjutnya dilakukan uji signifikansi dan linearitas persamaan regresi antar variabel. Hasil perhitungan uji signifikansi dan linearitas disusun pada tabel ANAVA seperti pada Tabel 2, Tabel 3, dan Tabel 4. 
Tabel 2. ANAVA untuk Uji Signifikansi dan Linearitas Persamaan Regresi $\hat{\mathbf{X}}_{\mathbf{3}}=69,50+0,45 \mathbf{X}_{1}$

\begin{tabular}{|c|c|c|c|c|c|c|}
\hline \multirow{2}{*}{$\begin{array}{l}\text { Sumber } \\
\text { Varians }\end{array}$} & \multirow{2}{*}{$\mathrm{dk}$} & \multirow{2}{*}{ JK } & \multirow{2}{*}{ RJK } & \multirow{2}{*}{ Fhitung } & \multicolumn{2}{|c|}{$F_{\text {tabel }}$} \\
\hline & & & & & $\alpha=0,05$ & $\alpha=0,01$ \\
\hline Total & 80 & 1000281 & & & & \\
\hline Regresi a & 1 & 996141,61 & & & & \\
\hline Regresi b/a & 1 & 918,64 & 918,64 & $22,25^{* *}$ & 3,96 & 6,97 \\
\hline Residu & 78 & 3220,75 & 41,29 & & & \\
\hline Tuna Cocok & 27 & 950,63 & 35,21 & $0,79 \mathrm{~ns}$ & 1,71 & 2,13 \\
\hline Galat & 51 & 2270,12 & 44,51 & & & \\
\hline
\end{tabular}

Tabel 3. ANAVA untuk Uji Signifikansi dan Linearitas Persamaan Regresi $\hat{\mathbf{X}}_{\mathbf{3}}=77,04+0,34 \mathbf{X}_{2}$

\begin{tabular}{|c|c|c|c|c|c|c|}
\hline \multirow{2}{*}{$\begin{array}{l}\text { Sumber } \\
\text { Varians }\end{array}$} & \multirow{2}{*}{$\mathrm{dk}$} & \multirow{2}{*}{ JK } & \multirow{2}{*}{ RJK } & \multirow{2}{*}{ Fhitung } & \multicolumn{2}{|c|}{ Ftabel } \\
\hline & & & & & $\alpha=0,05$ & $\alpha=0,01$ \\
\hline Total & 80 & 1000281 & & & & \\
\hline Regresi a & 1 & 996141,61 & & & & \\
\hline Regresi b/a & 1 & 988,47 & 988,47 & $24,47^{* *}$ & 3,96 & 6,97 \\
\hline Residu & 78 & 3150,92 & 40,40 & & & \\
\hline Tuna Cocok & 34 & 1320,88 & 38,85 & 0,93 ns & 1,69 & 2,11 \\
\hline Galat & 44 & 1830,04 & 41,59 & & & \\
\hline
\end{tabular}

Tabel 4. ANAVA untuk Uji Signifikansi dan Linearitas Persamaan Regresi $\hat{\mathbf{X}}_{\mathbf{2}}=59,15+0,47 \mathbf{X}_{1}$

\begin{tabular}{|c|c|c|c|c|c|c|}
\hline \multirow{2}{*}{$\begin{array}{l}\text { Sumber } \\
\text { Varians }\end{array}$} & \multirow{2}{*}{$\mathrm{dk}$} & \multirow{2}{*}{ JK } & \multirow{2}{*}{ RJK } & \multirow{2}{*}{ Fhitung } & \multicolumn{2}{|c|}{$F_{\text {tabel }}$} \\
\hline & & & & & $\alpha=0,05$ & $\alpha=0,01$ \\
\hline Total & 80 & 859586 & & & & \\
\hline Regresi a & 1 & 850781,25 & & & & \\
\hline Regresi b/a & 1 & 1002,96 & 1002,96 & $10,03^{* *}$ & 3,96 & 6,97 \\
\hline Residu & 78 & 7801,79 & 100,02 & & & \\
\hline Tuna Cocok & 27 & 2402,19 & 88,97 & $0,84 \mathrm{~ns}$ & 1,71 & 2,13 \\
\hline Galat & 51 & 5399,60 & 105,87 & & & \\
\hline
\end{tabular}

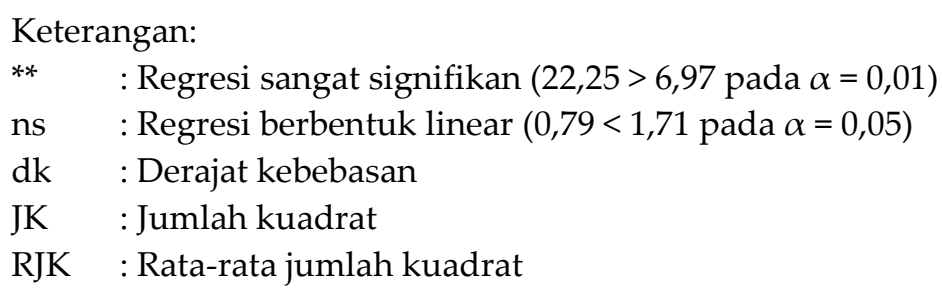

Selanjutnya dilakukan pengujian hipotesis dengan menghitung besaran nilai koefisien korelasi dan koefisien jalur. Dari hasil pengujian hipotesis pertama dapat disimpulkan bahwa terdapat pengaruh langsung positif pemberdayaan terhadap kinerja dengan nilai koefisien korelasi sebesar 0,471 dan nilai koefisien jalur sebesar 0,345. Ini memberikan makna pemberdayaan berpengaruh langsung positif terhadap kinerja. Dari hasil pengujian hipotesis kedua dapat disimpukan bahwa terdapat pengaruh langsung positif kepuasan kerja terhadap kinerja dengan nilai koefisien korelasi sebesar 0,489 dan nilai koefisien jalur sebesar 0,372. Ini memberikan makna kepuasan kerja berpengaruh langsung positif terhadap kinerja. Dari hasil pengujian hipotesis ketiga dapat disimpulkan bahwa terdapat pengaruh langsung positif pemberdayaan terhadap kepuasan kerja dengan nilai koefisien korelasi sebesar 0,338 dan nilai koefisien jalur sebesar 0,338. Ini memberikan makna pemberdayaan berpengaruh langsung positif terhadap kepuasan kerja. 


\section{Pengaruh Pemberdayaan terhadap Kinerja}

Pemberdayaan akan meningkatkan kinerja organisasi dan individu yang dapat mengembangkan bakatnya secara penuh. Selanjutnya menurut. Newstorm dan Davis (2015, p. 206) bahwa, "Empowerment is any process that provides greater autonomy to employees through the sharing of relevant information and the provision of control over factors affecting job performance".

Dalam definisi tersebut dijelaskan bahwa pemberdayaan merupakan proses yang memberikan otonomi yang lebih besar kepada seseorang melalui berbagai informasi yang relevan dan penyediaan kontrol atas faktor yang dapat mempengaruhi kinerja.

Sedangkan Russel dan Taylor (2006, p.319) mengemukakan bahwa, "empowerment is giving employees responsibility and authority to make decisions. Empowerment requires employees education and training and participation in goal setting".

Pemberdayaan adalah pemberian tanggung jawab pada pegawai dan pertimbangan untuk membuat keputusan. Pemberdayaan memerlukan pendidikan dan pelatihan serta partisipasi dalam penetapan tujuan yang akan berdampak kepada kinerja.

Pemberdayaan dapat dilakukan dengan saling berbagi informasi dan pengetahuan diantara seseorang yang digunakan untuk memahami dan mendukung kinerja organisasi, pemberian penghargaan pada peningkatan kinerja seseorang dan pemberian otonomi dalam pengambilan keputusan yang akhirnya berpengaruh baik terhadap organisasi. Seseorang menguasai pemahamannya, memiliki keterampilan baru dan diberi kesempatan melihat sesuatu dengan cara berbeda. Sehingga dapat merefleksikan apa yang dilihat dan mengembangkan keterampilan baru. Selanjutnya, McShane dan Glinow (2009, p. 183) berpendapat bahwa "With the right individuals, job characteristics, and organizational environment, empowerment can substantially improve motivation and performance".

Dengan Individu yang tepat, karakteristik kerja serta lingkungan suatu organisasi yang tepat pula, maka pemberdayaan secara substansial dapat meningkatkan motivasi dan kinerja seseorang. Berdasarkan uraian di atas, maka dapat disimpulkan bahwa pemberdayaan berpengaruh langsung positif terhadap kinerja seseorang.

\section{Pengaruh Kepuasan Kerja terhadap Kinerja.}

Kepuasan kerja adalah hasil persepsi seseorang mengenai pekerjaannya. Jika seseorang mengalami perasaan positif saat bekerja, maka orang tersebut dapat melakukan pekerjaan lebih baik lagi sehingga berdampak kepada kinerja/prestasi kerjanya. Menurut McShane dan Glinow (2009, p.111) mengatakan bahwa, "Job performance leads to job satisfaction (rather than vice versa), but only when performance is linked to valued rewards. Higher performers receive more rewards and, consequently, are more satisfied than low-performing employees who receive fewer rewards".

Kinerja/Prestasi kerja mengarah kepada kepuasan kerja (daripada sebaliknya), tapi hanya jika kinerja terkait dengan suatu penghargaan. Seseorang yang bekerja lebih baik akan mendapatkan penghargaan lebih tinggi, konsekuensinya ia memiliki kepuasan kerja yang lebih tinggi dari karyawan dengan penghargaan dibawahnya.

Selanjutnya Kreitner dan Kinicki (2011, p.177) berpendapat mengenai keterkaitan yang positif antara kepuasan kerja dan hasil kerja/prestasi kerja karyawan. Menurutnya keterkaitan yang positif tersebut tdak terlepas dari peran manager atau atasan, "... It thus appears managers can positively affect a variety of important organizational outcomes, including performance, by increasing employee job satisfaction".

Manajer dapat secara positif mempengaruhi berbagai hasil yang penting dari organisasi, termasuk kinerja, dengan meningkatkan kepuasan kerja karyawan. Dengan kata lain, karyawan yang lebih puas akan pekerjaannya akan menunjukkan kinerja yang lebih baik disbanding sebaliknya. Lebih lanjut Kinicki dan Angelo (2011, p.177) mengatakan, "Job performance one of the biggest controversies within $O B$ research centers on the relationship between job satisfaction and job performance. This is an important finding because it support the belief that employee job satisfaction is a key work attitude manager should consider when attempting to increase employees job performance". 
Kinerja adalah salah satu kontroversi terbesar dalam pusat penelitian perilaku organisasi tentang hubungan antara kepuasan kerja dan kinerja. Ini merupakan temuan penting karena keyakinan bahwa kepuasan kerja karyawan adalah sikap manajer yang penting dalam mempertimbangkan ketika mencoba untuk meningkatkan kinerja.

\section{Pengaruh Pemberdayaan terhadap Kepuasan kerja.}

McShane dan Glinow (2009, p.183) mengatakan bahwa, "A study reported that empowerment is associated with higher trust in management, which ultimately influences job satisfaction, belief and acceptance of organizational goals and values, and effective organizational commitment."

Sebuah studi melaporkan bahwa pemberdayaan dikaitkan dengan kepercayaan yang lebih tinggi dalam manajemen, yang akhirnya mempengaruhi kepuasan kerja, kepercayaan dan penerimaan tujuan organisasi dan nilai, serta efektivitas dari komitmen organisasi itu sendiri. Hal senada diungkapkan oleh Janazs (2009, p.389) yang menyatakan bahwa, "Empowerment is reinforces member participation and growth, commitment to quality, and a more open, honest environment. This result in greater job satisfaction, motivation, and commitment- a sense achivement."

Dengan diberdayakan, karyawan akan memperkuat partisipasi anggota dan perkembangan, komitmen terhadap kualitas, lingkungan yang jujur dan lebih terbuka. Hal ini menyebabkan peningkatan dalam kepuasan kerja, motiivasi dan komitmen.

Selanjutnya, Fisk (Ibrahim dan Shaleh, 2013, p.252) mengemukakan bahwa, "Empowered employees are more satisfied with their jobs, have an increased sense of personal efficacy through participation in decisionmaking and are encouraged to utilize a wide set of skills and abilities to address different scenarios."

Karyawan yang diberdayakan lebih puas dengan pekerjaannya, memiliki rasa peningkatan keberhasilan pribadi melalui partisipasi dalam pengambilan keputusan dan didorong untuk memanfaatkan serangkaian luas keterampilan dan kemampuan untuk mengatasi skenario yang berbeda.

Amir dan Amen (2014, p.13-26) menyatakan bahwa, "When employees are empowered, their confidence degree and self-reliance will increase. The extra confidence is a good thing because it create job satisfaction and high levels of productivity."

Ketika karyawan diberdayakan, tingkat kepercayaan diri dan kemandiriannya akan meningkat. Kepercayaan extra adalah hal yang baik karena ia menciptakan kepuasan kerja dan tingkat produktivitas yang tinggi. Dalam hal ini pemberdayaan, keterlibatan karyawan dengan organisasi dan sesama rekan kerja serta penghargaan akan menumbuhkan perasaan puas karyawan akan pekerjaannya. Karyawan diberikan otonomi yang lebih luas dalam melaksanakan berbagai tugas, fungsi dan kewajibannya, diberdayakan potensinya, diberi motivasi. Karyawan didorong untuk berbuat lebih kreatif dan inovatif dalam bekerja, dihargai kreatifitasnya yang ditujukan demi keberhasilan organisasi. Keadaan inilah yang meningkatkan kepuasan kerja.

\section{SIMPULAN}

Setelah semua tahap penelitian tentang pengaruh pemberdayaan dosen dan kepuasan kerja dosen terhadap kinerja dosen dilakukan, mulai dari pembuatan proposal penelitian, kemudian pengkajian teori, penyusunan instrument penelitian yang disertai dengan uji coba dan penyempurnaan instrument penelitian, sampai dengan pengumpulan data, pengolahan dan analisis data.

Pada akhirnya penulis dapat menyimpulkan hasil penelitian tentang pengaruh pemberdayaan dosen dan kepuasan kerja dosen terhadap kinerja dosen di Universitas Majalengka, dapat ditarik kesimpulan yakni: 1) Hipotesis I yang menyatakan terdapat pengaruh langsung dan positif antara pemberdayaan terhadap kinerja dosen Universitas Majalengka, artinya peningkatan pemberdayaan akan memperbaiki kinerja dosen dalam bertugas; 2) Hipotesis II yang menyatakan terdapat pengaruh langsung dan positif antara kepuasan kerja terhadap kinerja dosen Universitas Majalengka, artinya ketika terjadi peningkatan kepuasan dalam bekerja maka terjadi juga peningkatan pada kinerja dosen; 3) Hipotesis III yang menyatakan terdapat pengaruh langsung dan 
positif antara pemberdayaan dan kepuasan kerja dosen Universitas Majalengka. Artinya ketika pemberdayaan ditingkatkan maka kepuasan kerja dosen pun mengalami peningkatan.

\section{REFERENSI}

de Janasz, S. C. (2009). Interpersonal Skills in Organization. Booston: McGraw-Hill/Irwin.

McShane, S. L., \& Von Glinow, M. A. (2009). Organizational Behavior. New York: McGraw Hill Higher Education.

Newstorm, J. W. (2015). Organizational Behavior Human Behavior at Work. 14 ${ }^{\text {th }}$ edition. New York: McGraw Hill.

Saif, N. I., \& Saleh, A. S. (2013). Psychological empowerment and job satisfaction in Jordanian hospitals. International Journal of Humanities and Social Science, 3(16), 250-257.

Rivai, V. (2011). Performance Appraisal. Jakarta: Raja Grafindo Persada.

Robert Kreitner, Angelo Kinicki. (2011). Organizational Behavior. $9^{\text {th }}$ Edition. New York: McGrawHill.

Russell, R. S., \& Taylor, B. W. (2006). Operations management: Quality and competitiveness in a global environment. New Jersey: John Wiley \& Sons.

Schermerhorn, J. R. (2010). Introduction to Management. New Jersey: John Wiley \& Sons.

Sedarmayanti. (2011). Manajemen Sumber Daya Manusia. Bandung: Refika Aditama. 